\title{
Septicaemia due to Pasteurella pneumotropica
}

\author{
BOGUMILA T. ROGERS, J. C. ANDERSON, CYNTHIA A. PALMER, AND \\ W. G. HENDERSON
}

From the Department of Microbiology, The Royal Free Hospital, London

SYNOPSIS The literature concerning Pasteurella pneumotropica infection in animals and man is briefly reviewed and a case presented in which the organism was the cause of septicaemia in a patient receiving chemotherapy for myeloid leukaemia. Bacteriological findings are recorded and compared with those of other authors.

Pasteurella pneumotropica was first described, studied, and so named by Jawetz $(1948,1950)$ and Jawetz and Baker (1950). This organism, latent in normal mice, and in rats, guinea pigs, and hamsters associated with infected mouse colonies, produced a necrotizing pneumonia in mice only and on serial passage only. In view of this apparent predilection for the lung, a pneumotropism having characteristically no regard for inoculation route, the name Pasteurella pneumotropica was proposed.

Although a survey of five laboratory animal breeding establishments in the eastern United States at that time revealed none that was free from this organism, epizootics attributable to it had not been observed. Later workers confirmed the observations on latency (Hoag, Wetmore, Rogers, and Meier, 1962; Flynn, Brennan, and Fritz, 1965; Goldstein and Green, 1967) and primary pathogenicity (Gray and Campbell, 1953; Flynn et al, 1965; Brennan, Fritz, and Flynn, 1965; Innes, Garner, and Stookey, 1967; Wheater, 1967), and contributed observations on secondary invasion and opportunism (Wheater, 1967; Brennan, Fritz, and Flynn, 1969). Since the original observations of Jawetz, Pasteurella pneumotropica has been isolated from mice having pneumonia (Gray and Campbell, 1953; Brennan et al, 1965; Weisbroth, Scher, and Boman, 1969), conjunctivitis, metritis, cystitis, pleural abscess, peritoneal abscess, and dermatitis (Brennan et al, 1965), together with superficial abscess of the skin, panophthalmitis, and orbital abscess (Weisbroth et al, 1969). Pneumonia in the rat, hamster, and dog, conjunctivitis in the kangaroo, rat, and otitis, renal abscess, septicaemia, and peritonitis in the dog have also been recorded (Brennan et al, 1965).

The association of Pasteurella pneumotropica with Received for publication 10 April 1973. human disease, however, is rare. We have found in the literature six cases only. Two strains investigated by Henriksen and Jyssum (1961) and Henriksen (1962) were isolated in large numbers in both cases from the nose of a boy aged 16 years with maxillary sinusitis, and from the throat of a boy, aged 7 years, with rhinitis, recurrent tonsillitis, and enlarged adenoids. Two further instances were mentioned by Miller (1966). The first concerned a man aged 51 years who, having been bitten by a dog, developed septicaemia within 48 hours, followed rapidly by collapse and death. Necropsy showed haemorrhage and necrosis of the adrenals as in the WaterhouseFriderichsen syndrome. Pasteurella pneumotropica was recovered from the patient's blood and the dog's mouth. The second concerned a physician bitten on a finger by a dog with clinical pneumonitis, nasal discharge, and cough. Pyrexia, with pain and induration of the wound, developed within a few hours. A purulent discharge, from which Pasteurella pneumotropica was isolated, appeared next day. The patient, who was treated with dimethylchlortetracycline, recovered completely. No mention was made regarding isolation of Pasteurella pneumotropica from the dog. The fifth case, again with severe local sepsis in an adult, followed a cat bite (Olson and Meadows, 1969).

In the sixth case reported by Winton and Mair (1969) the organism was recovered from the wound of a patient who had been bitten on a finger by a dog and developed local inflammation. She was treated with oral penicillin and the wound healed without further event. No record was made of whether any lymphangitis or adenitis developed.

\section{Case Report}

An actor, aged 57 when first seen, gave a six weeks' 
history of unaccustomed tiredness and breathlessness accompanied by tachycardia, even after walking short distances. Although anorexia had been present for three months there was no loss of weight. Apart from flecks of blood following nose blowing, bleeding from orifices or bruising had not occurred. The past history included an episode of haematuria 10 years previously and pneumonitis 15 years previously.

On admission he was pale and ill, with a temperature of $38^{\circ} \mathrm{C}$; lymph nodes, liver, and spleen were not enlarged. The haemoglobin was $6.3 \mathrm{~g}$ $(43 \%)$, WBC $1300 / \mathrm{cmm}$, platelets $18000 / \mathrm{cmm}$. The bone marrow features were consistent with a diagnosis of acute myeloblastic leukaemia.

A remission induced with Daunorubicin and cytosine arabinoside was maintained with 6-mercaptopurine for eight months, after which relapse necessitated readmission, and further chemotherapy supported by blood and platelet transfusion. During the course of treatment and 10 days after admission, the patient developed a temperature of $40^{\circ} \mathrm{C}$ preceded by a sore throat. This, however, was not related to blood or platelet transfusion. Blood cultures yielded a non-motile Gram-negative bacillus having the characteristics of Pasteurella pneumotropica and sensitive by preliminary standard disc tests to penicillin, ampicillin, oxytetracycline, chloramphenicol, kanamycin, polymyxin, carbeni- cillin, cephalothin, gentamicin, and sulphamethoxazole/trimethoprim combination. This organism was not isolated from throat swabs or sputum on the first or second admissions.

Treatment with chloramphenicol followed by ampicillin caused the patient to become apyrexial and blood cultures to become sterile in four days. Two days later the temperature rose to $40.6^{\circ} \mathrm{C}$ accompanied by severe hypotension. He died the same day. Antemortem blood cultures yielded Klebsiella aerogenes. Postmortem appearances were those of left ventricular failure and pulmonary oedema.

\section{Bacteriology}

Primary isolation was achieved on blood cultures at $37^{\circ} \mathrm{C}$ from Castaneda's medium (Southern Group Laboratories) incubated aerobically and in carbon dioxide, and also from brain-heart infusion broth containing $0.1 \%$ agar.

Subsequent growth at $37^{\circ} \mathrm{C}$ was abundant on horse's blood or chocolate agar, less so, on nutrient agar, and absent on MacConkey's or desoxycholate medium. Colonies on blood agar at 18 hours were $1 \mathrm{~mm}$ in diameter, not haemolytic, greyish with a smooth surface, convex, and round with an entire edge. A strong odour resembling that of Haemophilus influenzae was also noted. Morphologically

\begin{tabular}{|c|c|c|c|c|c|c|c|c|c|c|c|}
\hline \multirow{2}{*}{$\begin{array}{l}\text { Biochemical } \\
\text { Characteristics }\end{array}$} & \multicolumn{11}{|c|}{ Results in Other Series } \\
\hline & 1 & 2 & 3 & 4 & 5 & 6 & 7 & 8 & 9 & 10 & 11 \\
\hline Gelatin & - & - & $\ldots$ & - & - & - & $\ldots$ & - & - & $\ldots$ & - \\
\hline Indol & + & + & + & + & + & + & + & + & + & + & + \\
\hline Nitrate reduction & + & + & + & + & $\ldots$ & $\ldots$ & + & + & + & $\ldots$ & + \\
\hline Urease & $\ldots$ & + & + & + & + & + & + & + & + & + & + \\
\hline Catalase & $\ldots$ & + & $\ldots$ & + & + & + & + & + & + & + & + \\
\hline Oxidase & $\ldots$ & + & + & + & + & + & + & + & + & + & + \\
\hline $\mathrm{H}_{2} \mathrm{~S}$ & $d^{3}$ & $+^{2}-4$ & $t^{2}$ & -4 & $\ldots$ & $-1+2$ & $t^{2}$ & +3 & $t^{2}$ & $-1+2$ & $-1+8$ \\
\hline MR/VP & $-1 \ldots$ & $-1-$ & $-1-$ & $-1-$ & $-1-$ & $-1-$ & $-1-$ & $-1-$ & $-1-$ & $\ldots$ & $-1-$ \\
\hline MacConkey agar & - & - & - & $\ldots$ & - & $\ldots$ & - & - & - & - & - \\
\hline Malonate & $\ldots$ & $\ldots$ & $\ldots$ & - & $\ldots$ & $\ldots$ & - & - & - & $\ldots$ & - \\
\hline Arabinose & d & $\ldots$ & - & d & - & $\ldots$ & + & + & - & $\ldots$ & - \\
\hline Glucose & + & + & + & + & + & + & + & + & + & + & $+^{*}$ \\
\hline Inositol & + & $\ldots$ & $\ldots$ & - & - & - & $\ldots$ & - & - & $\ldots$ & - \\
\hline Lactose & + & + & - & + & - & + & + & + & - & - & - \\
\hline Maltose & + & + & + & + & + & + & + & + & + & + & - \\
\hline Mannitol & $\ldots$ & d & - & - & - & - & - & - & - & - & - \\
\hline Mannose & + & $\ldots$ & $\ldots$ & $\ldots$ & + & $\ldots$ & + & + & + & $\ldots$ & $\ldots$ \\
\hline Rhamnose & - & $\ldots$ & - & - & - & $\ldots$ & - & - & - & $\ldots$ & - \\
\hline Salicin & - & d & - & $\ldots$ & - & $\ldots$ & - & - & - & $\ldots$ & - \\
\hline Sorbitol & d & $\ldots$ & - & - & - & $\ldots$ & - & - & - & $\ldots$ & - \\
\hline Sucrose & + & + & + & + & + & + & + & + & + & + & $+*$ \\
\hline Xylose & - & $\ldots$ & + & + & - & + & + & + & - & $\ldots$ & - \\
\hline Trehalose & $\ldots$ & + & $\ldots$ & $\ldots$ & + & $\ldots$ & $\ldots$ & $\ldots$ & + & $\cdots$ & $+*$ \\
\hline
\end{tabular}

Table I Comparison of biochemical characteristics of Pasteurella pneumotropica

1 Jawetz (1950), 2 Hoag, Wetmore, Rogers, and Meier (1962), 3 Henriksen (1962), 4 Heyl (1963), 5 Smith and Thal (1965), 6 Brennan, Fritz, and Flynn (1965), 7 Wheater (1967), 8 Weisbroth, Scher, and Boman (1969), 9 Winton and Mair (1969), 10 Olson and Meadows (1969), 11 present strain.

*Small amount of gas present, d variable, $\mathrm{H}_{2} \mathrm{~S}, 1$ tested on Kligler medium, 2 lead acetate strip, 3 method not stated, 4 iron salts incorporated in medium. 


\begin{tabular}{lllllllll}
\hline $\begin{array}{l}\text { Benzyl- } \\
\text { penicillin }\end{array}$ & Ampicillin & Cephaloridine & Erythromycin & Tetracycline & $\begin{array}{l}\text { Chloram- } \\
\text { phenicol }\end{array}$ & Kanamycin & Gentamycin & Polymyxin \\
\hline 0.3 & 0.15 & 0.15 & 0.25 & 0.8 & 1.25 & 1.25 & 0.6 & 1.0 \\
\hline
\end{tabular}

Table II MIC of antibiotics for Pasteurella pneumotropica $(\mu \mathrm{g} / \mathrm{ml})$

the organism was a small Gram-negative coccobacillus non-motile at 37 and $22^{\circ} \mathrm{C}$, which did not show bipolar staining. Biochemical activities are shown in table I, antibiotic sensitivities in table II. We concluded that the organism was Pasteurella pneumotropica.

Confirmation of the identity of our strain was subsequently obtained at the National Collection of Type Cultures Laboratory in a computer-assisted identification and given the number A 141/71.

Comparisons between the biochemical activities of Pasteurella pneumotropica strains obtained by various workers are shown in table I. Those of Jawetz (1950) utilized inositol but not xylose. By contrast those of Heyl (1963), Brennan et al (1965), Wheater (1967), and Weisbroth et al (1969); utilized xylose but not inositol or mannitol. While our own results are in harmony with those of Smith and Thal (1965), in that neither inositol or xylose were utilized, they differed from all others in the production of small amounts of gas in glucose, sucrose, and trehalose.

\section{Comment}

Although in our case Pasteurella pneumotropica was undoubtedly acting as an opportunist invader, the other examples of human infection so far recorded, scanty though they may be, would suggest that its abilities as a primary pathogen should not be underestimated.

We are indebted to Dr Nigel Compston for permission to publish, to Dr S. P. Lapage, National Collection of Type Cultures, and to our colleagues of the Departments of Morbid Anatomy and Haematology, the Royal Free Hospital. Our thanks are due also to our typists Mrs Mary Watts and Mrs Kathleen Bell.
References

Brennan, P. C., Fritz, T. E., and Flynn, R. J. (1965). Pasteurella preumotropica: cultural and biochemical characteristics and its association with disease in laboratory animals. Laboratory Animal Care, 15, 307-312.

Brennan, P. C., Fritz, T. E., and Flynn, R. J. (1969). Role of Pasteurella pneumotropica and Mycoplasma pulmonis in murine pneumonia. J. Bact., 97, 337-349.

Flynn, R. J., Brennan, P. C., and Fritz, T. E. (1965). Pathogen status of commercially produced laboratory mice. Laboratory Animal Care, 15, 440-447.

Goldstein, E., and Green, G. M. (1967). Alteration of the pathogenicity of Pasteurella pneumotropica for the murine lung caused by changes in pulmonary antibacterial activity. J. Bact., 93, 16511656 .

Gray, D. F., and Campbell, A. L. (1953). The use of chloramphenicol and foster mothers in the control of natural pasteurellosis in experimental mice. Aust. J. exp. Biol., 31, 161-166.

Henriksen, S. D., and Jyssum, K. (1961). A study of some Pasteurella strains from the human respiratory tract. Acta path. microbiol. scand., 51, 354-368.

Henriksen, S. D. (1962). Some Pasteurella strains from the human respiratory tract. Acta path. microbiol. scand., 55, 355-356.

Heyl, J. G. (1963). A study of Pasteurella strains from animal sources. Antonie $V$. Leeuwenhoek, 29, 79-83.

Hoag, W. G., Wetmore, P. W., Rogers, J., and Meier, H. (1962). A study of latent Pasteurella infection in a mouse colony. $J$. infect. Dis., 111, 135-140.

Innes, J. R. M., Garner, F. M., and Stookey, J. L. (1967). Respiratory disease in rats. In Pathology of Laboratory Rats and Mice, edited by E. Cotchin and F. J. C. Roe, pp. 237-240. Blackwell, Oxford. Davis Philadelphia.

Jawetz, E. (1948). A latent pneumotropic Pasteurella of laboratory animals. Proc. Soc. exp. Biol. (N.Y.), 68, 46-48.

Jawetz, E. (1950). A pneumotropic Pasteurella of laboratory animals. I. Bacteriological and serological characteristics of the organism. J. infect. Dis., 86, 172-183.

Jawetz, E., and Baker, W. H. (1950). A pneumotropic Pasteurella of laboratory animals. II. Pathological and immunological studies with the organism. J. infect. Dis., 86, 184-196.

Miller, J. K. (1966). Human pasteurellosis in New York State. N. Y. St. J. Med., 66, 2527-2531.

Olson, J. R., and Meadows, T. R. (1969). Pasteurella pneumotropica infection resulting from a cat bite. Amer. J. clin. Path., 51, 709710.

Smith, J. E., and Thal, E. (1965). A taxonomic study of the genus Pasteurella using a numerical technique. Acta path. microbiol. scand., 64, 213-223.

Weisbroth, S. H., Scher, S., and Boman, I. (1969). Pasteurella pneumotropica abscess syndrome in a mouse colony. J. Amer. vet. med. Ass., 155, 1206-1210.

Wheater, D. F. W. (1967). The bacterial flora of an SPF colony of mice, rats and guinea-pigs. In Husbandry of Laboratory Animals, edited by M. L. Conalty, pp. 343-360. Academic Press, London.

Winton, F. W., and Mair N. S. (1969). Pasteurella pneumotropica isolated from a dog-bite wound. Microbios, 2, 155-162. 